\title{
The Development of Early Childhood Motor through Human Resource Empowerment of PAUD Teacher Using Educational Game Tools in Maos Lor, Cilacap District, Central Java Province
}

\author{
Dodi Satriawan*1, Betti Widianingsih ${ }^{2}$, Fadhillah Hazrina ${ }^{3}$, Ayu Pramita ${ }^{4}$ \\ State Polytechnic of Cilacap; Dr. Soetomo St Number 1 Sidakaya, Central Java, (0282) 533329 \\ ${ }^{1,4}$ Program Studi Teknik Pengendalian Pencemaran Lingkungan, Politeknik Negeri Cilacap \\ ${ }^{2,3}$ Program Studi Teknik Listrik, Politeknik Negeri Cilacap \\ e-mail: ${ }^{* 1}$ dodi.unsri05@gmail.com, ${ }^{2}$ betti_widianingsih@yahoo.com, \\ 3imfadhillah21@gmail.com
}

Informasi Artikel
Diterima Redaksi: 08 August 2019
Revisi Akhir: 16 August 2019
Diterbitkan Online: 27 Sept 2019
Kata Kunci
PAUD, Motorik, APE, Edukaso, Tutor

Korespondensi

No. HP: +6282226695564

\begin{abstract}
Improving education and training of teacher as a focus on reformation of educational system which is a goal that must be achieved in EFA (Education for All). As a tangible manifestation of the mandate through efforts to improve the quality of education and development of competency based on educational game tools or APE. PAUD teachers should also have the ability to design, create, utilize, maintain, and self-assess the tools for early childhood games because well-developed game tools will be more interesting than tools that were not developed first. This community service program activity is needed because the education level of PAUD teachers varies. Based on the results of the identification of the target audience, most PAUD teachers do not meet the academic qualifications and competencies properly. The ability to read, write, count, think actively and critically and the low implementation of learning models in the form of quality and fun educational teaching aids in PAUD institutions is very necessary. The expected output of this activity is the increasing, competency and quality of PAUD teachers towards educational gamebased media learning programs (APE) and increasing the creativity of PAUD students by implementing APE-based learning media programs.
\end{abstract}

\section{PENDAHULUAN}

Di era modern sekarang ini, perkembangan ilmu pegetahuan dan teknologi telah menjadi pemicu berlangsungnya perubahan yang sangat pesat pada berbagai kehidupan baik individu maupun masyarakat umum. Salah satunya yang berlokasi di kecamatan di Kabupaten Cilacap. Maos adalah salah satu kecamatan di Kabupaten Cilacap Propinsi Jawa Tengah. Kecamatan ini berbatasan dengan Kecamatan Sampang di sebelah utara, Kecamatan Kroya di Timur, Kecamatan Adipala sebelah selatan dan Kecamatan Kesugihan di sebelah barat (http://www.cilacapkab.go.id). 


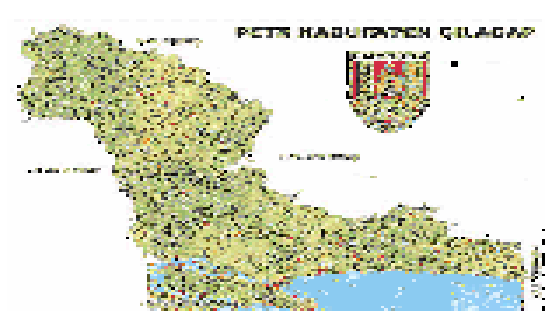

Gambar 1. Peta Kabupaten Cilacap

Menurut data statistik, Maos memiliki luas daerah sebesar $34,5 \mathrm{~km} 2$ dan jumlah penduduknya sebesar 64.238 jiwa yang terdiri dari 4 (empat) dusun yang terdiri dari Buaran, Lancar, Tengah dan Palinggihan. Total perangkat desa di Maos Lor adalah 44 RT, 15 RW (http://www.cilacapkab.go.id).

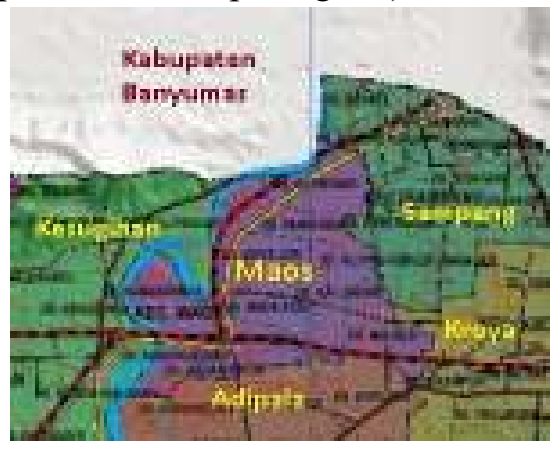

Gambar 2. Peta Desa Maos Lor

Peningkatan pendidikan dan pelatihan guru sebagai fokus pada reformasi sistem pendidikan merupakan tujuan yang wajib tercapai dalam EFA (Education For All). Sesuai laporan UNESCO dalam The International Commission on Education for Twenty-First Century menyatakan bahwa "memperbaiki mutu pendidikan pertama tama tergantung perbaikan perekrutan, pelatihan, status sosial, dan kondisi kerja para guru". Berbicara mengenai kualitas sumber daya manusia, pendidikan memegang peran yang sangat penting dalam proses peningkatan kualitas sumber daya manusia.

Sebagai wujud nyata mewujudkan amanat tersebut adalah melalui upaya meningkatkan kualitas pendidikan dan pengembangan kompetensi berbasis alat permainan edukatif atau APE. Perlu diketahui bahwa kegiatan belajar anak di lembaga PAUD dlakukan melalui bermain.
Bermain merupakan suatu kegiatan yang sangat digemari oleh anak usia dini dan kegiatan bermain pada anak pada intinya adalah proses belajar anak itu sendiri.

Pendidikan berawal dari tenaga pendidiknya yaitu guru, dimana mereka adalah bagian utama dalam kegiatan belajar mengajar baik lingkungan formal maupun non formal. Oleh karena itu, pendidik PAUD pun juga hendaknya memiliki kemampuan merancang, membuat, memanfaatkan, memelihara, dan menilai sendiri alat permainan untuk anak usia dini karena alat permainan yang dikembangkan dengan baik akan lebih menarik daripada alat yang tidak dikembangkan terlebih dahulu.

Di Dusun Palinggihan PAUD yang ada belum memiliki Sumber Daya Manusia yang sesuai standar. Hal tersebut dikarenakan kurangnya pelatihan yang diperoleh tenaga pendidik di POS PAUD MELATI VII Dusun Palinggihan Desa Maos Lor Kecamatan Maos Kabupaten Cilacap sehingga pencapaian untuk anak didik pun akan berpengaruh. Kegiatan program pengabdian masyarakat ini diperlukan karena beberapa aspek, yang dapat dirinci sebagai berikut:

1. Menurut pada PP No. 19 Tahun 2005 Tentang Standar Nasional Pendidikan pada pasal 28 dan 29 menyatakan bahwa pendidik anak usia dini harus memiliki kualifikasi akademik dan kompetensi yang memadai sebagai agen pembelajar. Kualifikasi akademik yang harus dipenuhi oleh pendidik Anak Usia Dini yakni berpendidikan minimum diploma empat (D-IV) atau Sarjana (S1). Persyaratan lain antara lain berlatar belakang pendidikan tinggi di bidang pendidikan anak usia dini, kependidikan lain, atau psikologi, dan memiliki sertifikat profesi guru untuk PAUD. Kompetensi pendidik PAUD yang harus dipenuhi meliputi: (a) kompetensi pedagogik, (b) kompetensi 
kepribadian, (c) kompetensi profesional, (c) kompetensi sosial.

2. Berdasarkan hasil identifikasi di lokasi pengabdian terhadap khalayak sasaran ternyata sebagian besar guru PAUD belum memenuhi kualifikasi akademik dan kompetensi sebagaimana yang diamanatkan dalam Peraturan Pemerintah tersebut. Pengalaman mengajar guru PAUD yang memiliki kualifikasi akademik SMA/sederajat pada umumnya sudah mengajar diatas 5 tahun. Kualifikasi akademik, pengalaman mengajar, pengalaman pelatihan yang relevan serta kompetensi yang belum terpenuhi dan memadai berpengaruh terhadap kualitas pembelajaran yang diselenggrakan oleh guru PAUD tersebut. Pendidik PAUD sebagai ujung tombak dan fasilitator dalam berlangsungnya pembelajaran, hendaknya memiliki pemahaman yang memadai dan menyeluruh mengenai alat permainan dan pengembangannya yang digunakan untuk anak usia dini karena alat permainan ini selain dapat memenuhi kebutuhan naluri bermainnya juga sebagai sumber yang mutlak diperlukan untuk mengembangkan seluruh aspek perkembangan anak usia dini.

3. Alat permainan sebagai sumber belajar yang mengandung makna bahwa alat permainan tersebut dirancang, dibuat, dan dimanfaatkan untuk memberikan kemudahan kepada anak dalam kegiatan bermainnya (belajar). Tujuan alat permainan edukatif sebagai media pembelajaran yang wajib dikuasai oleh tenaga pendidik PAUD adalah untuk membantu anak usia dini melatih motorik halusnya buat perkembangan kognitifnya

4. Tingginya tuntutan orang tua terhadap kemampuan membaca, menulis, berhitung, berfikir aktif dan kritis di lembaga POS PAUD Melati VII Dusun
Palinggihan. Berdasarkan hasil wawancara singkat yang dilakukan secara informal oleh peneliti terhadap Ibu $\mathrm{Hj}$, Mujiati selaku perwakilan dari guru POS PAUD Melati VII menunjukan bahwa sebagian besar orang tua di Dusun Palinggihan, Desa Maos Lor mengharapkan agar anakanak mereka memiliki keterampilan membaca dan menulis dengan baik, serta mampu berfikir aktif dan kritis sehingga mampu merangsang imajinasi kreatif mereka untuk berkembang. Alasan-alasan yang mendorong tingginya tuntutan ini diantara lain adalah sebagai persiapan anak memasuki pendidikan lanjut yakni Sekolah Dasar.

5. Rendahnya implemenatsi model pembelajaran berbentuk alat peraga edukatif yang berkualitas dan menyenangkan di lembaga TK dan PAUD. Mayke Sugianto, T. (1995), mengemukakan bahwa alat permainan edukatif (APE) adalah alat permainan yang sengaja dirancang secara khusus untuk kepentingan pendidikan.

6. Berdasarkan data-data yang disajikan di atas, maka perlu adanya program Peningkatan Kemampuan Motorik Anak Usia Dini Menggunakan Alat Permainan Edukatif (APE) yang dilaksanakan secara profesional, berjenjang dan terencana dengan baik di Dusun Palinggihan, Desa Maos Lor, Kecamatan Maos, Kabupaten Cilacap, Provinsi Jawa Tengah.

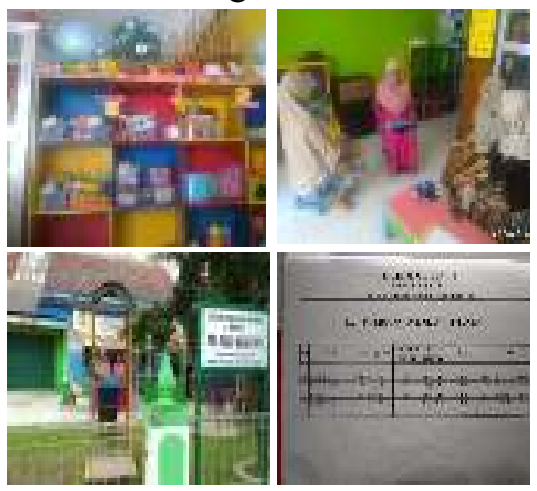


Gambar 3. Kondisi POS PAUD MELATI VII

Melihat permasalahan di atas maka, Politeknik Negeri Cilacap melalui kegiatan Pengabdian Kepada Masyarakat ini memberikan beberapa jenis APE yang sesuai dengan sistem pembelajaran yang dicanangkan oleh pemerintah dan pelatihan tentang pengaplikasian APE secara langsung kepada guru PAUD. Kegiatan ini dilakukan sebagai upaya untuk meningkatkan kemampuan Sumber Daya Manusia (Guru PAUD) yang diharapkan dapat merancang, membuat, dan memanfaatkan APE sebagai alat untuk memberikan kemudahan kepada anak dalam kegiatan bermainnya (belajar). Pelatihan dilakukan dengan pembagian kelompok APE yang akan digunakan masing-masing guru PAUD dengan melihat secara langsung pengaplikasiaan mereka kepada siswa didik. Selain itu, dilakukan evaluasi terhadap Sumber Daya Manusia (Guru PAUD) untuk mengetahui seberapa tinggi tingkat kepahaman penerapan APE pada sistem pembelajaran di lingkungan Pendidikan Anak Usia Dini (PAUD).

\section{METODE}

Berdasarkan target luaran yang ingin dicapai, maka metode yang dipilih dalam kegiatan pengabidan kepada masyarakat adalah pengembangan media pembelajaran melalui pemberian sarana dan prasarana serta pelatihan khusus dalam bentuk pendampingan implementasi alat permainan edukatif (APE). Pelaksanaan kegiatan pengabdian kepada masyarakat berikut ini dilaksanakan selama 3 (tiga) bulan dalam rentang waktu 1 (satu) tahun. Implementasi penggunaan alat permainan edukatif (APE) dilakukan oleh masingmasing guru Pos PAUD Melati VII yang dilibatkan dalam pengabdian masyarakat ini. Metode pelaksanaan pengabdian kepada masyarakat yang dilakukan dpat dirinci sebagai berikut:
1. Melakukan observasi dengan cara survei lapangan dan wawancara ke sekolah POS PAUD Melati VII, Desa Maos Lor khususnya Dusun Palinggihan, Kabupaten Cilacap, untuk mengetahui kondisi, permasalahan, kebutuhan dan potensi yang dapat dikembangkan.

2. Menganalisis kebutuhan data yang dibutuhkan terkait dengan permasalahan di sekolah POS PAUD Melati VII yang akan diselesaikan.

3. Menyiapkan material yang dibutuhkan berupa dokumen dan perangkat keras yang berupa alat permainan edukatif (APE) untuk membantu meminimalisisr permasalahan yang terjadi pada objek sesuai dengan hasil yang diperoleh pada kegiatan 1 dan 2.

4. Melakukan koordinasi dengan objek untuk menyusun dan membuat kesepakatan tentang proses dan jadwal pelaksanaan program pengabdian kepada masyarakat, agar tidak mengganggu kegiatan rutinitas sekolah POS PAUD Melati VII yang telah terjadwal.

5. Melaksanaan kegiatan pengabdian kepada masyarakat yang diawali dengan sosialisasi awal dengan memberikan pelatihan khusus tentang penerapan media pembelajaran dalam bentuk Alat Permainan Edukatif (APE) oleh guru Pos PAUD Melati VII kepada siswa anak usia dini.

6. Melakukan evaluasi terhadap penguasaan materi yang disampaikan, yaitu materi tentang penggunaan dan penerapan Alat Permainan Edukatif (APE).

7. Melakukan evaluasi dan umpan balik terhadap pelaksanaan program pengabdian kepada masyarakat yang telah dilaksanakan. 
Kegiatan pengabdian kepada masyarakat dilaksanakan sesuai dengan harapan, oleh karena itu dalam proses kegiatan dilakukan persiapan dan pembuatan prosedur (SOP) pelaksanaan program. Prosedur pelaksanaan program yang dilaksanakan dalam program kegiatan pengabdian kepada masyarakat ini sebagai berikut:

1. Observasi, prosedur yang dilaksanakan pada observasi ini yaitu sebagai berikut:

a. Survei lapangan, yang bertujuan untuk mengetahui kondisi objek secara langsung

b. Wawancara, yang bertujuan untuk mengetahui permasalahan yang dihadapi oleh guru PAUD, metode pembelajaran yang dilakukan, hasil belajar siswa, potensi yang dapat dikembangkan, dan fasilitas yang dapat dimaksimalkan dan dimanfaatkan.

2. Analisis kebutuhan data, prosedur yang dilaksanakan untuk melakukan analisis kebutuhan data aalah dengan mencari informasi terkait hal berikut ini:
a. Kurikulum pembelajaran yang diterapkan,
b. Sumber-sumber pembelajaran yang digunakan
c. Kegiatan bermain yang diterapkan.

3. Menyiapkan material yang dibutuhkan, yaitu:

a. Perangkat keras yang berupa alat permainan edukatif (APE)

b. Dokumen yang harus dipersiapkan berupa soft copy dan hard copy: file presentasi, media sosialisasi, daftar hadir, dokumentasi, serta file evaluasi analisis dan kinerja pengabdian kepada masyarakat.

4. Pelaksanaan dan prosedur pelaksanaan kegiatan diuraikan sebagai berikut: a. Pembukaan, oleh Ketua Tim dan Anggota Tim yang terdiri dari 4 personil didampingi oleh perangkat Dusun setempat di Desa Maos Lor, Kabupaten Cilacap.

b. Penjelasan proses kegiatan dan gambaran umum media pembelajaran menggunakan Alat Permainan Edukatif (APE) sebagai media penunjang perkembangan motorik anak dalam merangsang kemampuan motorik anak usia dini dan sebagai bentuk peningkatan profesionalisme guru

c. Penerapan media pembelajaran menggunakan Alat Permainan Eduatif (APE) yang dirancang secara khusus untuk kepentingan pendidikan dan berfungsi untuk mengembangkan aspek-aspek perkembangan anak dalam hal ini adalah aspek motorik anak usia dini yang dapat merangsang kemampuan kognitif anak oleh guru Pos PAUD Melati VII,

d. Penutupan secara resmi dilakukan oleh pelaksana pengabdian kepada masyarakat, guru Pos PAUD Melati VII didampingi oleh perangkat desa setempat Dusun Palinggihan, Desa Maos Lor.

5. Evaluasi, prosedur ini terdiri dari:

a. Melakukan tanya jawab baik secara formal kepada guru Pos PAUD Melati VII, maupun informal kepada siswa PAUD secara random (acak) dan masyarakat sekitar sekolah (jika ada).

b. Melaksanakan praktek media pembelajaran yang dilakukan oleh pelaksana pengabdian kepada masyarakat kepada 4 guru Pos PAUD Melati VII Dusun Palinggihan, Desa Maos Lor, Kabupaten Cilacap. 
c. Menerapkan media pembelajaran yang telah dipraktekan oleh trainee (pelaksana pengabdian kepada masyarakat) sebelumnya yaitu Alat Permainan Edukatif (APE) kepada anak usia dini di Pos PAUD Melati VII Dusun Palinggihan, Desa Maos Lor, Kabupaten Cilacap. Selain itu sebagai bentuk feedback atau respon dari pelatihan yang diberikan kepada guru Pos PAUD adalah hendaknya seluruh guru Pos PAUD melalui kegiatan ini diharapkan memiliki kemampuan untuk merancang, membuat, memanfaatkan, memelihara, dan menilai sendiri alat permainan untuk anak usia dini karena alat permainan yang dikembangkan dengan baik akan lebih menarik dari pada alat yang tidak dikembangkan terlebih dahulu

Umpan balik kegiatan ini dilakukan dengan cara wawancara baik dengan siswa PAUD maupun guru PAUD Melatih VII, untuk mengetahui kekurangan, kelemahan serta masukan untuk meningkatkan kinerja dari pengabdian kepada masyarakat ini.

\section{3}

\section{HASIL DAN PEMBAHASAN}

Pelaksanaan kegiatan pengabdian kepada masyarakat dengan judul peningkatan motorik anak usia dini melalui pemberdayaan SDM guru PAUD menggunakan Alat Permainan Edukatif (APE) di Desa Maos Lor, Kecamatan Maos, Kabupaten Cilacap, Propinsi Jawa Tengah, dilaksanakan selama 2 hari penuh di jam kerja. Kegiatan pertama dilaksanakan pada tanggal 13 September 2018 dan kegitan kedua dilaksanakan pada tanggal 14 September 2018. Kegiatan pengabdian hari pertama bertujuan untuk memberikan penyuluhan dan pengenalan APE terhadap Ibu-ibu pengajar POS PAUD MELATI VII serta pelatihan penggunaan
APE kepada guru-guru POS PAUD MELATIH VII. Sedangkan kegiatan pengabdian hari kedua bertuan untuk melihat dan menilai kemampuan guru-guru POS PAUD MELATIH VII dalam menggunakan dan menerapkan APE ke siswa-siswi POS PAUD MELATIH VII.

\subsection{Tahap Penyuluhan dan Pelatihan Penggunaan APE}

Kegiatan pemberian penyuluhan dan pengenalan APE bertujuan untuk memberikan informasi kepada guru-guru POS PAUD MELATIH VII tentang pentingnya pertumbuhan dan perkembangan anak-anak usia dini. Penyuluhan ini diberikan oleh Ibu Rofiah Akbar, M.Psi, Psikolog. Penyuluhan ini berisikan :

a. Pertumbuhan dan Perkembangan anak-anak

Pertumbuhan dan perkembangan yang terjadi semasa usia dini akan menjadi fondasi bagi anak-anak di masa dewasa. Pada usia ini merupakan MASA KEEMASAN (GOLDEN $A G E)$ pada anak-anak usia dini. Mereka akan tumbuh, berkembang dan belajar dengan kecepatan yang berbeda dengan anak yang seusianya.

b. Pentingnya PAUD dikaitkan dengan perkembangan otak anak usia dini

Saat lahir bayi memiliki sekitar 100 milyar sel otak yang saling bersambungan. Sel-sel otak ini akan saling bersambung dengan berbagai pengalaman indera dari benyaknya rangsangan yang diterimanya. Ransangan indera ini akan memperkuat dan memperbanyak sambungan (synaps) antar sel. Banyaknya sambungan akan menjadikan otak rimbun yang turut menentukan tingkat kecerdasan anak nantinya. $50 \%$ perkembangan kecerdasan anak terjadi pada usia 0-4 
tahun, dan $50 \%$ sisanya pada rentang usia 4-18 tahun

c. Pembentukan Synaps

Usia pembentukan synaps berlangsung pada tiga fase usia, yaitu

- Fase lahir - 3 tahun. Pada fase ini pembentukan synaps sangat cepat.

- Fase usia 3 - 8 tahun. Pada fase ini kepadatan synaps 2 kali lipat orang dewasa.

- Fase usia 8 - 18 tahun. Pada fase ini terjadi pemangkasan atau penurunan kepadatan synaps

d. Perbedaan pertumbuhan dan perkembangan

Pertumbuhan adalah perubahan secara kuantitatif berarti pertumbuhan dalam ukuran fisik sedangkan Perkembangan adalah perubahan yang bersifat kualitatif, perubahan secara kuantitatif akan diikuti oleh perubahan dalam fungsi (perkembangan).

e. Dua faktor dominan perkembangan

- Nature, merupakan faktor yang dibawa sejak lahir seperti warna rambut, warna suara, bentuk mata, watak, intelegensi dan lain-lain.

- Nutrure, merupakan aspek pengasuhan yang bisa memunculkan aspek nature (bawaan) seperti lingkungan fisik (alam tempat tinggal), lingkungan sosial (keluarga, masyarakat, sekolah) dan pola perlakuan dari lingkungan sosial

f. Manfaat stimulasi

Otak manusia terdiri dari jutaan saraf. Stimulasi diberikan agar terjadi hubungan hubungan (network) antara satu saraf dengan saraf lain. Sehingga kelak saat ia memasuki usia sekolah, otaknya akan lebih mudah menerima dan menyimpan pesan dari luar. Stimulus sendiri adalah kegiatan merangsang secara memadai kemampuan dasar anak agar tumbuh dan berkembang optimal sesuai potensi yang dimilikinya. Yang disebut perangsangan yang memadai adalah perangsangan yang dilakukan dengan benar, adekuat, dan teratur, sesuai kelompok umur anak.

g. Orang yang boleh menstimulasi anak Stimulasi pada anak sebaiknya dilakukan oleh orang-orang terdekat seperti ayah, ibu, pengganti ibu, pengasuh, pendidik serta anggota keluarga lain. Hal ini disebabkan karena orang terdekat biasanya akan menunjukkan perilaku baik yang dilandasi kasih sayang.

h. Komponen aktifitas area yang distimulasi pada anak usia dini.

Ada 4 (empat) komponen aktifitasnya area yang distimulasi pada anak usia dini, yaitu:

- Aktifitas Motorik.

Aktifitas motorik dibagi menjadi 2 yaitu:

- Aktifitas Motorik Kasar

Motorik kasaryaitu aktifitasaktifitas yang memerlukan kemampuan koordinasi otot-otot besar pada tubuh. Aktifitas motorik kasar berupa berguling, duduk, merangkak, berjalan, berlari,melompat, lempar/tangkap bola, mendrible bola, menendang bola, meniti, naik/turun tangga, dan meluncur di prosotan.

- Aktifitas Motorik Halus

Keterampilan motorik halus (fine motor skill) adalah aktifitasaktifitas yang memerlukan pemakaian otot-otot kecil pada tangan. Seperti memegang benda kecil seperti manik-manik, butiran kalung, memegang sendok, memegang pensil dengan benar, menggunting, melipat kertas, mengikat tali sepatu, mengancing, dan menarik resleting.s

- Aktifitas Kognitif 
Pada tahap ini, anak berusaha memahami keterampilan motorik serta apa saja yang dibutuhkan untuk melakukan satu gerakan tertentu.

- Aktifitas Asosiatif

Pada tahap ini, anak banyak belajar dengan cara coba-coba, kemudian meralat olahan pada penampilan atau gerakan akan dikoreksi agar tidak melakukan kesalahan kembali dimasa mendatang.

- Aktifitas Autonomous

Pada tahap ini, gerakan yang ditampilakan anak merupakan respon yang lebih efisien dengan sedikit kesalahan, anak sudah menampilkan gerakan secara otomatis.

i. Peran Guru POS PAUD

Peran guru POS PAUD ada 10 (sepuluh) yaitu:

- Mengembangkan fiisk motorik anak yang dapat dilakukan melalui bermain.

- Menentukan aktifitas fisik atau olahraga yang dapat dilakukan anak sesuai dengan pertumbuhan dan perkembangannya.

- Menumbuhkan minat anak terhadap berbagai kegiatan motorik anak seperti olahraga menggambar, melipat kertas, dan lain-lain.

- Mengarahkan dan menumbuhkan minat anak untuk mengikuti semua kegiatan fisik motoric agar gerakan motorik kasar dan halus dapat dikembangkan dengan baik.

- Membantu mengembangkan minat dan rasapercaya diri anak dan penasaran untuk mampu melakukan berbagai kegiatan fisik motorik yang sesuai dengan anak PAUD.

- Meningkatkan kemampuan dan kekuatan otot anak. Perkembangan kekuatan otot tersebut diimbangin dengan perkembangan dalam mengkoordinasikan gerakan antara otot yang satu dengan otot yang lain.

- Meningkatkan gerakan motorik kasar anak sehingga keterampilan motorik halus yang telah dimiliki anak akan meningkat.

- Menentukan tujuan yang akan dicapai. Guru perlu menentukan gerak dan keterampilan yang perlu dikuasai anak melalui pelaksanaan beberapa kegiatan pembelajaran.

- Menentukan bagaimana cara menilai hasil belajar anak serta melaporkan hasilnya kepada orang tua didik.

- Membantu mengembangkan keterampilan motorik anak PAUD dengan cara merencanakan dan mengatur secara baik lingkungan belajar dna proses belajar anak untuk mencapai tujuan pengembangan motorik.

j. Sarana dan Prasarana yang dilakukan guru untuk membantu meningkatkan gerakan motorik anak usia dini, yaitu:

- Menyediakan peralatan atau lingkungan yang memungkinkan untuk melatih keterampilan motoriknya.

- Memperlakukan anak dengan sama

- Memperkenalkan berbagai kenis keterampilan motorik.

- Aktifitas fisik yang diberikan ke anak harus bervariasi.

- Berilah anak - anak aktifitas fisik yang memungkinkan anak menikmati dan dapat mencapai kemampuan yang diharapkan sesuai perkembangannya.

- Saat melakukan aktifitas fisik yang menempatkan anak bersama beberapa anak lain.

Atas bantuan dan kerjasama dari seluruh guru POS PAUD MELATIH VII 
Dususn Palinggihan, desa Maos Lor, Kecamatan Maos, Kabupaten Cilacap, Jawa Tengah, kegiatan pengabdian kepada masyarakat dapat terlaksana dengan baik, lancer, dan sesuai yang direncanakan. Setelah kegiatan ini diharapkan meningkatkan motorik anak usia dini melalui pemberdayaan SDM guru POS PAUD MELATIH VII dalam menggunakan Alat Permainan Edukatif (APE). Salah satu outcome dari kegiatan pengabdian kepada masyarakat ini adalah dapat membantu pemerintah dalam menerapkan PP No.19 Tahun 2015 tentang Standar Nasional Pendidikan pada Pasal 28 dan 29 yang menyatakan bahwa pendidik anak usia dini harus memiliki kualifikasi akademik dan kompetensi yang memadai sebagai agen pembelajar.

\section{KESIMPULAN}

Pengabdian ini secara umum dapat meningkatkan motorik siswa didik untuk dapat tumbuh kembang secara optimal menggunakan sistem pembelajaran yang sesuai. serta memberdayakan Sumber Daya Manusia melalui Guru PAUD dalam mengaplikasikan APE dalam lingkungan non-formal sesuai sistem pembelajaran yang dicanangkan pemerintah. Selain itu pengabdian ini dapat meningkatkan pengetahuan serta kemampuan merancang, membuat dan memanfaatkan jenis-jenis APE secara optimal sesuai sistem pembelajaran dari pemerintah agar siswa didik dapat memiliki bekal yang cukup melanjutkan ke tingkat TK. Sedangkan APE dapat meningkatkan kemampuan motorik halus buat perkembangan kognitif siswa didik sehingga memiliki hasil lulusan PAUD yang berkualitas.

\section{SARAN}

Selanjutnya untuk meningkatkan sarana dan prasarana dibidang pendidikan dapat dilengkapi dengan sistem permainan edukatif yang dibuat dengan memanfaatkan teknologi Internet of Things. Selain mudah digunakan dalam kehidupan sehari - hari, juga dapat menambah nilai guna alat permainan yang dulunya konvensional saat ini bisa diterapkan secara mobile.

\section{UCAPAN TERIMA KASIH}

Seluruh Tim Pelaksana ucapkan terimakasih atas dukungan baik moral maupun materiil yang diberikan dalam pelaksaan program pengabdian ini kepada Bapak Soedihono, Dipl.Ing., S.T., M.T selaku Direktur Politeknik Negeri Cilacap yang telah memberikan kesempatan dan membantu dalam segi materiil (dana) sehingga dapat terlaksanannya kegiatan ini, Bapak Galih Mustiko Aji, ST.,M.T. ,selaku Ketua PPPM Politeknik Negeri Cilacap yang telah memberikan kesempatan memberikan saran, masukan dan bantuannya. Ibu Hj. Mujiati, selaku Ketua Pengelola POS PAUD MELATI VII Dusun Palinggihan Desa Maos Lor yang berkenan memberikan kesempatan dan waktu serta menyediakan tempat untuk terlaksanannya kegiatan ini, serta ibu-ibu Guru POS PAUD MELATI VII Dusun Palinggihan Desa Maos Lor yang telah banyak memberikan bantuan agar terlaksanannya kegiatan ini dengan lancar.

\section{DAFTAR PUSTAKA}

Aprilia, Kartika. (2016). Penggunaan Alat Permainan Edukatif (APE) Dalam Mengembangkan Kemampuan Mengenai Ukuran Pada Anak Usia Dini 4-5 Tahun di TK Hip Hop Bandar Lampung. Universitas Lampung. Lampung.

Ardipal. (2009). Peningkatan Kualitas Guru Anak Usia Dini Dalam Upaya Pengembangan Sumber Daya Manusia Berkualitas di Masa Depan. Jurnal Bahasa dan Seni Vol 10 No. 1 Tahun 2009 (68 - 74).

Badruzaman. (2010). Pengembangan Alat Peraga Edykatif di Lembaga PAUD 
(Bahan PPG Guru PAUD UPI).

Bandung.

Direktorat Pendidikan Anak Dini Usia. (2003). Alat Permainan Edkatif untuk Kelompok Bermain. Jakarta : Depdiknas.

Direktorat Pendidikan Anak Dini Usia. (2003). Pembuatan dan Penggunaan APE (Alat Permainan Edukatif) Anak Usia 3-6 Tahun. Jakarta : Depdiknas.

Elyawati, Cucu. (2005). Pemilihan dan Pengembangan Sumber Belajar Untuk Anak Usia Dini. Jakarta : Depdiknas.

Hernawati, Adya. (2017). Upaya Peningkatan Kompetensi dan Kualitas Pendidikan Anak Usia Dini Berbasis Alat Peraga Edukatif Motorik di Pos PAUD Kelurahan Merjosari Kota Malang. Universitas Widyagama Malang.

Nuraini, Rahayu. (2015). Peningkatan Mutu Pendidikan di Pendidikan Ank Usia Dini (PAUD) Fatimah Desa Purbayan Kecamatan Baki Kabupaten Sukoharjo.

Sudono Anggani,. (2000). Sumber Belaar dan Alat Permainan Anak PAUD. Jakarta. Grasindo.

Wiranti, Novia. (2015). Pengembangan Profesionalitas Guru Taman Kanak Kanak Bersertifikasi. Universitas Negeri Yogyakarta. Yogyakarta.

Zaman, Badru. Pengembangan Alat Permainan Edukatif Di Lembaga Pendidikan Anak Usia Dini (PAUD). 